\title{
UNVEILING THE OVERLOOKED FREEDOM \\ - THE CONTEXT OF FREE MOVEMENT OF \\ CAPITAL AND PAYMENTS IN THE EU LAW
}

\section{Ondrej Hamulák ${ }^{1}$}

\section{Faculty of Law, Palacký University in Olomouc, Czech Republic email: ondrej.hamulak@upol.cz.}

HAMULÁK, Ondrej. Unveiling the overlooked freedom - the context of free movement of capital and payments in the EU law. International and Comparative Law Review, 2012, Vol. 12., No. 2, pp. 129-145. DOI: 10.1515/iclr-2016-0091.

\begin{abstract}
Free movement of capital and payments represents the youngest of the freedoms within the single internal market of the European Union. The title "youngest" points on the very slow release of capital markets within the European Community and the European Union which leads to the tardy development of this freedom. It is young also from the view of the legal effects because it was the last of the freedom where direct effect of basal Treaty provision was accepted by the Court of Justice. In the heading of this article I awarded the forth freedom with the adjective "overlooked" which is clearly my subjective opinion on the approach of the EU law scholars to this part of the internal market law. In the most of the substantive textbooks and casebooks we may find only marginal space devoted to this field, especially in comparison with the other market freedoms. My objective is to offer and general introductive insight to this area and to certain extent cover the emerging gap.
\end{abstract}

Keywords: Capital, Payments, Free movement, Restrictions, Exemptions, Case-law

\section{The objectives}

Free movement of capital and payments represents the youngest of the freedoms within the single internal market of the European Union. The title "youngest" points on the very slow release of capital markets within the European Community and the European Union which leads to the tardy development of this freedom. It is young also from the view of the legal effects because it was the last of the freedom where direct effect of basal Treaty provision was accepted by the Court of Justice.

1 Faculty of Law, Palacký University in Olomouc, Czech Republic, e-mail: ondrej.hamulak@ upol.cz. 
In the heading of this article I awarded the forth freedom with the adjective "overlooked" which is clearly my subjective opinion on the approach of the EU law scholars to this part of the internal market law. In the most of the substantive textbooks and casebooks we may find only marginal space devoted to this field, especially in comparison with the other market freedoms. My objective is to offer and general introductive insight to this area and to certain extent cover the emerging gap.

\section{General introduction and historical developments}

Even though the founders of the European Economic Community defined this freedom as the integral part of the economic integration and they demanded at least some minimal liberalisation of the capital and payment flows ${ }^{2}$, the development was not satisfactory. Slower development of this freedom is associated with a lengthy release of capital markets and reluctance of states to deeper liberalization in this area. Free movement of capital and payments lies in cross-border transfers of financial assets, investing in shares and in immovable property, in the financial participation of foreigners in domestic enterprises etc. Cross-border investment is closely connected with the creation of the monetary union and the actual release of the markets for the investors has a significant connection with the area of state economic policy and taxation. ${ }^{3}$ The area of monetary sovereignty as well as the field of economic policies and fiscal autonomy of a state they all are a distinctive attributes of statehood and the Member States in these areas are hesitant to give up their powers. ${ }^{4}$

Different character of this freedom was upheld also by the Court of Justice. In its seminal decision 203/80 Casati $^{5}$ Court pointed out that the free movement of capital, in addition to the free movement of goods, persons and services, forms the fundamental freedom within the Community. But in one breath it refused to admit a direct effect of the provisions of former Article 67 of the Treaty establishing the European Economic Community. Thus Court halted the liberalization of capital movements and rather left that question to the Member States or other Community institutions. Its negative opinion was built mainly on the specific nature of the free movement of capital, which on the one hand can stimulate

2 See The Brussels Report on the General Common Market (known as Spaak Report). Available online at: http://aei.pitt.edu/995/1/Spaak_report.pdf. The Intergovernmental Committee on European Integration in this report (in Chapter 4, Section 2) determined that the free movement of capital would form part of the common market and would embrace acquisition, use and disposal of capital anywhere within the common market; the right to create a companies, to acquire shares in existing companies and to participate in their management.

3 See BARNARD, C.: The Substantive Law of EU: The four freedoms, 3rd ed., Oxford: Oxford University Press, 2010, p. 560.

4 See FALLON, M. Droit matérie generel de l'Union européenne. 2e edition. Louvain: Bruylant-Academia, 2002, s. 194-195.

5 Judgment of 11 November 1981, Casati, 203/80, ECR 1981 p. 2595. 
economic growth (investment, business development), but on the other hand, it may affect the economic and monetary policy of the state, distraught its balance of payments and thus adversely affect the functioning of the market. Further Court argued that the application of former Article 67 of the Treaty was dependent on the implementing measures and therefore could not have direct effect in within the national law. ${ }^{6}$

The most significant changes in the development of the free movement of capital and payments were introduced by the Maastricht Treaty. Maastricht in general brought a big change in the economic policy of the European Union by the inclusion of the new policy area - Economic and Monetary Policy. The close relation between this policy and liberalization of the capital flows was clear from the very beginning of integration. Maastricht treaty fulfilled the requirement of deeper linkage between the free movement of capital and the gradual development of economic and monetary union mainly by the let's say redefinition of the context of the fourth freedom. Generally speaking by the adoption of the Maastricht Treaty ${ }^{7}$ the free movement of capital and payments achieved formally the same level of integration like other freedoms of the internal market (concept of the freedom $=$ no restrictions + exceptions from this ban). The Maastricht Treaty changed the provisions relating to the free movement of capital and payments and for both categories introduced prohibition of restrictions. ${ }^{8}$ The importance of the Maastricht treaty lies also in fact that it united the issue of free movement of capital and free movement of payments (until this change of primary law both freedoms were understood in significantly different way - see next chapter). The change of the legal appraisal of free movement of capital and payments was later responded even by the Court of Justice which transformed its view on the possibility of direct applicability of the Treaty provisions. It found out that article $73 \mathrm{~b}$ of the EC Treaty in the Maastricht version is capable of having direct effect (C-163/94, C-165/94 and C-250/94 Sanz de Lera ${ }^{9}$. According to the Court this

6 What is in contrast to the Courts approach to another freedoms where the requirement of certain implementing or providing measures was not understand as obstacle to acceptation of direct effect of Treaty provision on freedom of establishment (Judgment of 21 June 1974, Reyners / Belgian State, 2/74, ECR 1974 p. 631) and free movement of services (Judgment of 3 December 1974, Van Binsbergen / Bedrijfsvereniging voor de Metaalnijverheid, 33/74, ECR 1974 p. 1299).

7 It is important here to note that Treaty provisions on the free movement of capital and payments came into the force on $1^{\text {st }}$ January 1994 and not on 1st November 1993 as the Maastricht treaty in general did.

8 Article $73 \mathrm{~b}$ of the EC Treaty in the Maastricht version stated:

"1. Within the framework of the provisions set out in this Chapter, all restrictions on the movement of capital between Member States and between Member States and third countries shall be prohibited.

2. Within the framework of the provisions set out in this Chapter, all restrictions on payments between Member States and between Member States and third countries shall be prohibited."

9 Judgment of 14 December 1995, Sanz de Lera and others, C-163/94, C-165/94 and 
article contains a clear and unconditional prohibition, which does not require further implementation and is therefore applicable in proceedings before national courts. The "Maastricht concept" of the freedom was maintained even after the adoption of the Lisbon Treaty and it applies till the present time (I will cover its contours below in this article).

\subsection{Capital versus Payments}

In the initial period of integration, free movement of capital and free movement of payments were treated as separate freedoms. Because of the differences between the two categories they were talked about as the fourth and fifth freedom of the common market. This was suggested mainly by separate legal regulation and basis. Free movement of capital was set out in Article 67 paragraph 1 TEC. ${ }^{10}$ Free movement of payments was set out in Article 106 paragraph 1 TEC. ${ }^{11}$ Another reason for distinguishing was the different regimes of both freedoms. It consisted in the fact that the same exceptions to the prohibition restriction applied to both of them, and also in the fact that the free movement of capital, respectively provisions of the Treaty regulating it, were not directly effective $\left(203 / 80\right.$ Casati $\left.^{12}\right)$, while the free movement of payments could be enforce before national courts (direct effect of the provisions on the free movement of payments was confirmed by the Court in decision 286/82 and 26/83 Luisi and Carbone ${ }^{13}$ ). Faster development (liberalization) for the free movement of payments was a logical consequence of their importance for building a common market. Liberalization of the market for goods and services and free movement of persons is necessarily required liberalization of transfer of payments between the Member States. In case 286/82 and 26/83 Luisi and Carbone (also later in judgment 308/86 Lambert ${ }^{14}$ ) the Court confirmed the assumption that they are two separate components of the common market. It pointed out that in the case of payments there is a transfer of counter-value, fulfilment for received goods or provided services, and in case of free movement of capital there is autonomous movement of financial values $=$ investment. Free movement of payments is connected with trade

C-250/94, ECR 1995 p. I-4821.

10 "1. Member States shall, in the course of the transitional period and to the extent necessary for the proper functioning of the Common Market, progressively abolish as between themselves restrictions on the movement of capital belonging to persons resident in Member States and also any discriminatory treatment based on the nationality or place of residence of the parties or on the place in which such capital is invested"

11 "Each Member State undertakes to authorise, in the currency of the Member State in which the creditor or the beneficiary resides, any payments connected with the exchange of goods, services or capital, and also any transfers of capital and wages, to the extent that the movement of goods, services, capital and persons is freed as between Member States in application of this Treaty"

12 Judgment of 11 November 1981, Casati, 203/80, ECR 1981 p. 2595.

13 Judgment of 31 January 1984, Luisi and Carbone / Ministero dello Tesoro, 286/82 and 26/83, ECR 1984 p. 377.

14 Judgment of 14 July 1988, Ministère public / Lambert, 308/86, ECR 1988 p. 4369. 
between entities from different Member States, it is primarily connected to an existing liability and meeting this liability. On contrary, free movement of capital is not tied to any previous trading, this case concerns investments and movement of fruits of investments (interests, dividends).

A different regime of both freedoms on the one hand and their similar nature (in both cases they in fact involved the transfer of financial values across borders) on the other hand led to complications - determining whether it was a case of free movement of capital free movement of payments was important mainly because of protections of individuals. The Treaty did not contain any legal definition of capital or payments that would differentiate them. Even Council Directive 88/361/EEC of 24 June 1988, implementing Article 67 of the Treaty, was not conducive in this regard. Although in Annex I it contained classification of free movement of capital, the list was not exhaustive (as was interpreted by the Court of Justice in C-222/97 Trummer $^{15}$ ).

As I mentioned above Maastricht reform removed existing problematic differentiation between free movement of capital and free movement of payments in a fundamental way. Since the Maastricht Treaty came into effect, we may speak of one freedom with two subcategories. Free movement of capital and payments are now significantly closer to one another. Both freedoms have parallel regime within the Union, they are subject to uniform legal regulation and one group of exceptions. But variations in external regime are preserved, i.e. concerning the free movement of capital and payments between Member States of the Union and third countries. Thanks to this approximation we may - in context of liberalization of movement of financial values within the EU - speak only of a single freedom. ${ }^{16}$

The above interpretation implies that the free movement of capital is connected with the transmission of the financial value across borders for the purpose of investment or in connection with the payment for received goods or services. Commission on its website clearly shows what categories of investments come under the free movement of capital:

- Foreign direct investment (FDI), including investments which establish or maintain lasting links between a provider of capital (investor) and an enterprise (in effect setting up, taking-over, or acquiring an important stake in a company or institution);

- Real estate investments or purchases;

- Securities investments (e.g. in shares, bonds, bills, unit trusts);

- Granting of loans and credits; and

15 Judgment of 16 March 1999, Trummer and Mayer, C-222/97, ECR 1999 p. I-1661.

16 Therefore, for the purposes of the following text, we will use the abbreviated name free movement of capital for both categories. Payments will be mentioned only if different regime applies to them. 
- Other operations with financial institutions, including personal capital operations such as dowries, legacies, endowments, etc. ${ }^{17}$

\section{Free movement of capital as a prohibition of restrictions}

In the Treaty, free movement of capital is constructed as prohibition of restrictions. Today, this prohibition is contained in Article 63 TFEU $^{18}$ (in the same form as in the time of its inclusion by Maastricht Treaty). The Treaty requires Member States to abandon measures that could constitute an obstacle to the free movement of capital and payments. In the primary law, of course, we do not find a definition or a list of prohibited restrictions. Due to the close connection between the free movement of capital and free movement of goods (monetary value of both, similar exceptions to the prohibition of restrictions), we may use the "Dassonville" definition to outline the "restrictions". ${ }^{19}$ In this regard, the prohibition would concern any "direct, indirect, actual or potential restrictions" on movement of capital.

For other freedoms of the internal market it is typical that they are "protected" by broad definition of the term prohibited restrictions. All of them are built as prohibition of discrimination on grounds of origin = nationality (goods, persons, services) as well as prohibition of other (non-discriminatory) restrictions that may adversely affect free movement. With free movement of capital, the system is kept and even here it applies that the Treaty prohibits both discrimination (direct and indirect) and other restrictions which, although applied indistinctly, may adversely affect the free movement of capital (C-302/97 Konle $\left.{ }^{20}\right)$. In case of discrimination, origin of capital is the criterion, in case of other restrictions it is the possibility of a negative impact on the free movement of capital. The key point is the free movement of capital (the Treaty does not distinguish whether it is a movement to or from a Member State), and therefore the prohibition of restrictions concerns both restrictions on "import" of capital, and restrictions on its "export” from a Member State. Article 63 TFEU prohibits:

- unequal treatment between domestic and foreign capital, i.e. discrimination (C-367/98 Commission v Portugal ${ }^{21}$ ),

- other forms of restrictions on the free movement of capital, such as the authorization scheme (also C-367/98 Commission v Portugal); in the

17 Available at http://ec.europa.eu/internal_market/capital/overview_en.htm\#what.

18 1. Within the framework of the provisions set out in this Chapter, all restrictions on the movement of capital between Member States and between Member States and third countries shall be prohibited.

2. Within the framework of the provisions set out in this Chapter, all restrictions on payments between Member States and between Member States and third countries shall be prohibited.

19 See TICHÝ, L. et al. Evropské právo. 4th ed. Praha: C. H. Beck, 2011, p. 500.

20 Judgment of 1 June 1999, Konle, C-302/97, ECR 1999 p. I-3099.

21 Judgment of 4 June 2002, Commission / Portugal, C-367/98, ECR 2002 p. I-4731. 
form of obstacles that may discourage from the exercise of free movement of capital (C-478/98 Commission v Belgium ${ }^{22}$ ); or in the form of measures that degrade movement of capital to just theoretical, illusory possibility (C-35/98 Verkooijen $\left.{ }^{23}\right)$.

The Court of Justice held that the prohibition of restrictions on free movement of capital has direct effect (C-163/94, C-165/94 and C-250/94 Sanz de Lera, or more recently $C-101 / 05$ Skatteverket ${ }^{24}$ ). According to the Court, Article 63 TFEU contains a clear and unconditional prohibition, which does not require further implementation and is therefore applicable in proceedings before national courts and in case of conflict with the national legislation it should take precedence.

\subsection{Prohibited restrictions - examples from the case-law}

The practice in the area of free movement of capital and application of the prohibition of restrictions brought several examples (we may say typical areas) where state measures concern this freedom and often negatively affect the liberalization of the movement of financial values. In this chapter we will look at the most typical examples of prohibited restrictive measures. There will be always at least one case study in each of the main areas to provide reader with the deep example. There is no space to offer a detailed analysis of all relevant cases here. The intent of this article is not to cover all important cases of the Court of Justice but to describe the main features of the fourth freedom of single market. Indeed there were some comprehensive studies of the development of the judicial approach. ${ }^{25}$

In next part I will turn my attention to the three categories of most common and most visible interferences to the freedom of movement of capital, concretely to the case of preservation of special rights in the hand of nationals which are generally known as golden shares; secondly to the area of taxation which is very "risky" zone once we are speaking about negative impacts on the free movement of capital; and thirdly I will speak about measures of state control over the capital and payment flows, where we are facing the conflict between state's financial stability and financial interests on one side and demands of the free market on the other side.

22 Judgment of 26 September 2000, Commission / Belgium, C-478/98, ECR 2000 p. I-7587.

23 Judgment of 6 June 2000, Verkooijen, C-35/98, ECR 2000 p. I-4071.

24 Judgment of 18 December 2007, A, C-101/05, ECR 2007 p. I-11531.

25 See FLYNN, L. Coming of Age: The Free Movement of Capital Case Law 1993-2002. Common Market Law Review, 2002, vol. 39, issue 4, pp. 773-805; MOHAMED, S. Recent case law in the field of free movement of capital. Journal of International Banking Regulation, 2001, vol. 3, no. 1, pp. 178-191; USHER, J. The Evolution of the Free Movement of Capital. Fordham International Law Journal, 2007, vol. 31, no. 5, pp. 1533-1570. 


\subsubsection{Golden shares cases $^{26}$}

The term "golden shares" refers to a category of shares in companies that are associated with special rights. The owners of such shares exercises these privileges beyond normal rights of shareholders (e.g. participation in important decisions regardless of the amount of their share, they must always approve person in management, etc.). Creating "golden shares" is a typical side-effect of privatization of state enterprises when states try to maintain some influence through them.

We already know that free movement of capital is built on an open investment environment. On grounds of this freedom, owners of funds should have the right to invest their assets anywhere. This investment must be associated with the same rights as those enjoyed by other investors in the same company (i.e. all shareholders). The very existence of the special rights may hinder free movement of capital or make the potential investment less attractive and thus discourage people from exercising this freedom granted by the EU law (C-58/99 Commission $v$ Italy $^{27}$ ).

CASE STUDY: As an example of illegal introduction of "golden shares" we may mention case C-171/08 Commission v Portugal ${ }^{28}$. In its decision the Court of Justice reiterated all the basic postulates of its approach to the issue of "golden shares". That is why the Commission refers to the judgment as a decision on "golden rules on golden shares". The judgment was pronounced in 2010 as part of infringement proceedings. Commission brought an action against Portugal and claimed that measures of this state violate rules on free movement of capital. Portuguese law on privatizations contained legislation under which statutes of privatized companies may provide for the existence of golden shares which are intended to remain state's property and which confer on the state a right of veto over amendment to the statutes and other decisions in the field of management of the company. Subsequently, the statutes of Portugal Telecom (PT) actually identify shares that could be held only by the state or other public sector shareholders and which were associated with certain preferential rights (e.g. that at least one third of the total number of directors in the board, including the chairman of the board, shall be elected by a majority of votes allocated to the state and other public sector shareholders). The Court criticized the legislation as contrary to freedom of movement of capital and condemned Portugal for breach of the Treaty. In its words: "[ $t$ ] he holding [by the Member State] of those golden shares, in so far as it confers on that State an influence on the management of the [company] which is not justified by the size of its shareholding in that com-

26 KRONENBERGER, V. The rise of the 'golden' age of free movement of capital: A comment on the golden shares judgments of the Court of Justice of the European Communities.

European Business Organization Law Review, 2003, vol. 4, no. 1, pp. 115-136.

27 Judgment of 23 May 2000, Commission / Italy, C-58/99, ECR 2000 p. I-3811.

28 Judgment of 8 July 2010, Commission / Portugal, C-171/08, ECR 2010 p. I-6817. 
pany, is liable to discourage operators from other Member States from making direct investments in that company, inasmuch as they could not be involved in the management and control of that company in proportion to the value of their shareholdings. [...] Similarly, the structuring of the special shares may have a deterrent effect on portfolio investments in the company in so far as a possible refusal by the State concerned to approve an important decision, proposed by the organs of the company concerned as being in the company's interests, is in fact capable of depressing the value of the shares of that company and thus reduces the attractiveness of an investment in such shares [...]" (see paragraphs 60 and 61 of the judgement).

\subsubsection{Area of taxation ${ }^{29}$}

Frequent restrictions/interferences to the free movement of capital result also from the application of national tax systems. While it is true that in the field of direct taxation the Member States enjoy autonomy (direct taxation falls within the competence of the Member States), the Court has repeatedly stated that the Member States must exercise that competence consistently with European Union law (C-311/97 Royal Bank of Scotland ${ }^{30}$ ). Application of tax rules (e.g. determining tax rates, rules on tax deductions and tax abatements, calculation of tax bases) in situations of movement of capital to and from abroad may not be stricter or less favourable than in the case of their application to wholly internal situations.

CASE STUDY: The Court gave its opinion on such prohibited unequal treatment for example in case C-315/02 Len $z^{31}$ - under Austrian tax system the earnings of companies (dividends) were taxed at different levels, according to whether the revenue was of Austrian or foreign origin. Different regime consisted in the fact that for income from capital of Austrian origin it was possible to enjoy tax benefits (adjusted tax rate reduced by half and taxation with discharging effect), while income from capital of foreign origin was taxed at the ordinary income tax (in the end, it was about twice the rate). A German national citizen Anneliese Lenz, subject to taxation in Austria, in her tax return for 1996 stated dividends from joined-stock companies established in Germany, whereupon she was assessed normal income tax on this income. Mrs Lenz considered the assessed tax as contrary to the rules of free movement of capital and in this sense she turned to Austrian courts with her claim. The question of conformity of the described Austrian legislation and requirement of European law came before the Court of Justice in the form of preliminary ruling. It stated that the legislation is not admissible within the meaning of the Treaty provisions. According to the Court, distinguishing taxes on dividends of Austrian and foreign origin

29 USHER, J. The Evolution of the Free Movement of Capital. Fordham International Law Journal, 2007, vol. 31, no. 5, pp. 1549-1562.

30 Judgment of 29 April 1999, Royal Bank of Scotland, C-311/97, ECR 1999 p. I-2651.

31 Judgment of 15 July 2004, Lenz, C-315/02, ECR 2004 p. I-7063. 
constitutes a restriction on the free movement of capital, because on the one hand it may deter Austrian entities from investing their capital in companies established in other Member States and on the other hand in relation to companies established in other member States it constitutes an obstacle to raising capital in Austria.

\subsubsection{State control/regulation of the movement of capital}

Regulation of movement of capital to and from a country is one of the classic tools of state (not only) economic policy. Adaptation of rules of export of financial values for residents or vice versa of financial values imported by non-residents is subject to so-called foreign exchange laws. States may for various reasons (security, environment, for reasons of tradition, preservation of local communities, etc.) regulate the possibility of foreigners to take possessions of real property on their territory. Movement of capital also applies to rules on investments and provision of banking services, such as e.g. preference of operations in domestic currency. These categories of measures, however, interfere with the free movement of capital and without proper justification they are not compatible with the requirements of EU law. The Court addressed the issue of state regulation in several decisions. Examples include the following:

CASE STUDY 1: "Exports of money" - C-163/94, C-165/94 and C-250/94 Sanz de Lera ${ }^{32}$. This case concerned the system of authorization for export of means of payment from Spain. According to Spanish law on economic transactions with other countries, exports of financial resources (coins, banknotes, cheques) was subject to a prior declaration when the amount concerned exceeded one million of pesetas and to a prior administrative authorization when the amount concerned exceeded five million pesetas. Penalties were applied in case of breach of these requirements (i.e. export of money without declaration or authorization). In three different cases the authorities found out that Mr Sanz de Lera, Mr Díaz Jiménez and Mrs Kapanoglu exported abroad the amount of more than five million pesetas. Because they did not have the proper export authorization from the Spanish authorities, criminal proceedings were instituted against these persons. National court, which decided the case, stayed the proceedings and referred questions to the Court of Justice for a preliminary ruling, which among other things asked about compliance of the described Spanish rules and Treaty provisions on the free movement of capital and payments. The Court stated that conditioning the export of funds by previous authorization constitutes a restriction that (since it is dependent on the discretion of a national authority) is not compatible with the provisions of the Treaty. Spanish government justified the need for authorization scheme by requirement of supervision and prevention of infringements. The Court did not accept its argument because the described

32 Judgment of 14 December 1995, Sanz de Lera and others, C-163/94, C-165/94 and C-250/94, ECR 1995 p. I-4821.

(c) Palacký University Olomouc, Czech Republic, 2012. ISSN 1213-8770 (print), ISSN: 2464-6601 (online). 
reasons of public interest could be achieved by more proportionate measures. In this spirit it then stated that the requirement of prior declaration is not contrary to the Treaty.

CASE STUDY 2: "Acquisition of immovable property by foreigners" C-302/97 Konle $^{33}$. This case concerned the acquisition of immovable property by foreigners in Austria. The so-called Tyrol law on the transfer of land from 1996 contained a rule that all future acquirers of land had the obligation to apply for authorization by a public authority. At the same time they had to show that the planned acquisition will not be used to establish a secondary residence. While the law did not distinguish between Austrians and foreigners, in the end it represented a potential restriction on the free movement of capital for investment in immovable property. This key issue became the subject of preliminary ruling in which the Court of Justice stated that conditioning acquisition of property by a foreign entity with a previous permission by the authorities of a Member State is incompatible with the free movement of capital. In its response the Austrian government advocated the system by the fact that previous authorization is an important tool of town and country planning policies which in certain regions help to maintain permanent population and economy activities dependent on the tourist sector. The Court acknowledged that the reasons pursue important public purpose. However, in order to be recognized as compatible with European law, it was necessary to prove that such measures are not discriminatory and that this purpose could not be achieved by other, less restrictive ways. However, according to the Court neither of these criteria was fulfilled in this case.

\section{Exceptions from the prohibition of restrictions on free movement of capital}

Prohibition of restrictions on the free movement of capital is not absolute, and both the Treaty itself and the case-law of the Court of Justice offer several categories of exceptions where it is possible for the Member States to intervene in otherwise liberalized free movement of capital. As with the other freedoms, in case of free movement of capital there are important interests protected by both the Member States and the European Union itself.

Compared to other freedoms, exceptions to the prohibition of restrictions on the free movement of capital, however, are connected to several specifics. In addition to classic reasons (protection of public policy or public security), there are special exceptions only for the typical problems of movement of capital and payments (issues of tax audits, statistics, fiscal oversight, etc.). Another particularity is related to the global nature of the free movement of capital. The Treaty allows other specific exceptions from the prohibition of free movement to and from third countries. Reasons of admissible restrictions are not a closed list,

33 Judgment of 1 June 1999, Konle, C-302/97, ECR 1999 p. I-3099. 
admissible are both written exceptions (explicitly mentioned in the Treaty) and unwritten exceptions - mandatory (important) requirements of general interest - they are discovered through the case-law of the Court of Justice.

\subsection{Explicitly stated reasons for derogation - written exceptions}

Explicit reasons for derogation of free movement of capital are determined directly by text of primary law and particularly by Article 64-66 TFEU. These reasons include a wide range of restrictions which may hinder free movement of capital and payments and still not be considered to be contrary to European Union law. The Treaty reflects the global nature of this freedom. But liberalization of capital movements in relation to third countries requires a special regime. Therefore, the Treaty provides specific categories of exceptions from the prohibition of restrictions on the free movement of capital to and from third countries. Restrictions on the free movement of capital can also be a tool of foreign and security policy (in the form of embargoes). In this regard, the Treaty contains relevant instruments (Article 75 and 215 of the TFEU).

\subsubsection{Historical third country restrictions}

Article 64 paragraph 1 TFEU $^{34}$ authorizes the restrictions against third countries which existed in the law of the Member States before the date of full liberalization of movement of capital, as at $31^{\text {st }}$ December 1993, respectively $31^{\text {st }}$ December 1999. This provision is sometimes denoted ad "grandfather" clause ${ }^{35}$. The reasons for the existence/retaining these exceptions are mainly historical. These dates are mandatory and the Court of Justice pointed out that measures restricting the free movement of capital to and from third countries under this Article must show some degree of legal continuity. "The words 'restrictions which exist on 31 December 1993' presuppose that the legal provision relating to the restriction in question have formed part of the legal order of the Member State concerned continuously since that date. If that were not the case, a Member State could, at any time, reintroduce restrictions on the movement of capital to or from third countries which existed as part of the national legal order on 31 December 1993 but had not been maintained." (C-101/05 Skatteverket $\left.{ }^{36}\right)$.

34 „1. The provisions of Article 63 shall be without prejudice to the application to third countries of any restrictions which exist on 31 December 1993 under national or Union law adopted in respect of the movement of capital to or from third countries involving direct investment - including in real estate - establishment, the provision of financial services or the admission of securities to capital markets. In respect of restrictions existing under national law in Bulgaria, Estonia and Hungary, the relevant date shall be 31 December 1999."

35 See TERRA, B., WATTEL, P. European Tax Law, 5th edition. Hague: Kluwer, 2008, p. 40.

36 Judgment of 18 December 2007, A, C-101/05, ECR 2007 p. I-11531. 


\subsubsection{New third country restrictions}

Member States agreed with the liberalization of free movement of capital also in relation to third countries, and thus they lost the opportunity to introduce new measures (this loss was compensated by retaining existing measures, see previous part). Power to adopt measures which would constitute a step backwards as regards the liberalization of the free movement of capital was conferred mainly upon the EU institutions (article 64 paragraph $3 \mathrm{TFEU}^{37}$ ). Such measures may be adopted only by the Council acting unanimously after consulting the European Parliament. Member States may adopt new measures in relation to third countries only in exceptional cases. They can do so only provided that (1) the Council did not exercise its (previously described) right, (2) measures concern only the area of taxation, (3) they are compatible with one of the Union's objectives and functioning of the internal market, and (4) they were approved by the Commission, respectively the Council (see Article 65, paragraph $4 \mathrm{TFEU}^{38}$ ).

\subsubsection{Short-term safeguard measures to third countries}

The provision of article $66 \mathrm{TFEU}^{39}$ allows the adoption of specific, exceptional measures on freedom of capital to and from third countries in a situation endangering the operation of economic and monetary union. Measures under this Article are adopted on a proposal from the Commission and after consulting the European Central Bank for a period not exceeding six months.

\subsubsection{General exceptions}

Article 65 paragraph $1 \mathrm{TFEU}^{40}$ contains admissible restrictions on the free movement of capital which are most associated with the functioning of the

37 „3. The measures and procedures referred to in paragraphs 1 and 2 shall not constitute a means of arbitrary discrimination or a disguised restriction on the free movement of capital and payments as defined in Article 63."

38 „4. In the absence of measures pursuant to Article 64(3), the Commission or, in the absence of a Commission decision within three months from the request of the Member State concerned, the Council, may adopt a decision stating that restrictive tax measures adopted by a Member State concerning one or more third countries are to be considered compatible with the Treaties in so far as they are justified by one of the objectives of the Union and compatible with the proper functioning of the internal market. The Council shall act unanimously on application by a Member State."

39 "Where, in exceptional circumstances, movements of capital to or from third countries cause, or threaten to cause, serious difficulties for the operation of economic and monetary union, the Council, on a proposal from the Commission and after consulting the European Central Bank, may take safeguard measures with regard to third countries for a period not exceeding six months if such measures are strictly necessary."

40 „1. The provisions of Article 63 shall be without prejudice to the right of Member States:

a) to apply the relevant provisions of their tax law which distinguish between taxpayers who are not in the same situation with regard to their place of residence or with regard to the place where their capital is invested;

b) to take all requisite measures to prevent infringements of national law and regulations, 
internal market. These exceptions do not distinguish between the movement of capital within the EU, or between the states of the Union and third countries. Yet their relevance is associated mainly with the movement of capital within the Union. This area of written (explicitly allowed) exemptions from the prohibition restriction on the free movement of capital is crucial because it allows Member States to introduce certain restrictions and to take measures that are necessary to protect important and current interests of their financial markets. Article 65, paragraph 1 contains several categories of exceptions. These are the grounds for derogation based on admissible "discrimination" in the tax area (C-319/02 Manninenem ${ }^{41}$ ), various protective measures associated with state control of the functioning of financial markets (C-439/97 Sando $z^{42}$ ) and ultimately the reasons of "public order" (C-54/99 Church of Scientology $\left.y^{43}\right)$. Although they are expressly permitted exceptions to the free movement of capital, the states may not abuse or use them in excessive way. The condition for their application is that they do not constitute a means of arbitrary discrimination or a disguised restriction on the free movement of capital (Article 65, paragraph 3 TFEU). Moreover, according to the Court of Justice measures taken on the basis of Article 65 paragraph 1 TFEU must be proportional, i.e. absolutely necessary in relation to the intended objective (C-54/99 Church of Scientology), and they cannot be based only on economic grounds (C-367/98 Commission $v$ Portugal $\left.{ }^{44}\right)$.

\subsubsection{Exceptions arising from restrictions on freedom of establishment}

In the last chapter we will speak about that the free movement of capital can also be called a service freedom, because movements of financial values across borders are connected to the exercise of other freedoms. Free movement of capital is connected to the free movement of persons, in particular the freedom of establishment (203/80 Casat $\left.i^{45}\right)$. Before starting a business in another Member State, entrepreneurs exercising the freedom of establishment must necessarily to transfer across borders certain amount of capital, which they intend to invest. Restrictions on the free movement of entrepreneurs (freedom of establishment), admissible under the Treaty or resulting from the mandatory requirements of public interest, can ultimately also lead to restrictions on the movement of capital (article 65 paragraph $2 \mathrm{TFEU}^{46}$ ). In order to make sense, the admissible

in particular in the field of taxation and the prudential supervision of financial institutions, or to lay down procedures for the declaration of capital movements for purposes of administrative or statistical information, or to take measures which are justified on grounds of public policy or public security."

41 Judgment of 7 September 2004, Manninen, C-319/02, ECR 2004 p. I-7477.

42 Judgment of 14 October 1999, Sandoz, C-439/97, ECR 1999 p. I-7041.

43 Judgment of 14 March 2000, Église de scientology, C-54/99, ECR 2000 p. I-1335.

44 Judgment of 4 June 2002, Commission / Portugal, C-367/98, ECR 2002 p. I-4731.

45 Judgment of 11 November 1981, Casati, 203/80, ECR 1981 p. 2595.

46 „2. The provisions of this Chapter shall be without prejudice to the applicability of restrictions on the right of establishment which are compatible with the Treaties." 
exceptions must affect both the freedom of establishment and the free movement of capital (C-492/04 Lasertec $\left.^{47}\right)$. Measures that hinder the free movement of entrepreneurs must therefore be primarily considered in the light of the rules on freedom of establishment (C-524/04 Test Claimants in the Thin Cap Group Litigation $\left.^{48}\right)$.

\subsubsection{Security exceptions}

The movement of capital (investment in the territory of a country and the export of capital $=$ investment abroad) is a major macroeconomic factor and the possibility of its regulation is an important political tool. In addition, the regulation of the flow of funds is also an important security tool. In the framework of its foreign and security policy, the European Union may use regulation of free movement of capital in order to reduce security risks (measures in the fight against terrorism, Article 75 TFEU) or to promote its values in the world and help to solve crises (measures within the common foreign and security policy). ${ }^{49}$

\subsection{The rule of reason - unwritten exceptions}

As with the other freedoms of the internal market, in case of free movement of capital practice has shown that explicit exceptions to the prohibition of restrictions on the free movement of capital are not sufficient. Diversity of legislation and the interests of the Member State requires that there are some reasonable deviations, exceptions to liberalization under which the States may restrict the free movement of capital and thus protect their own important reasons of public interest.

Theory of mandatory requirements of public interest, known from the caselaw on the free movement of goods and persons (120/78 Cassis with Dijon ${ }^{50}$ ), was confirmed by the Court of Justice also in the area of free movement of capital $\left(C-148 / 91\right.$ Veronika Omroep $\left.{ }^{51}\right)$. The Court of Justice recognized that restrictions on the free movement of capital may be justified by an overriding requirement of public interest. But this measure must apply indistinctly to all persons who carry out their activities in the territory of a Member State and the principle of proportionality must be respected (C-367/98 Commission $v$ Portugal $\left.{ }^{52}\right)$. Also

47 Order of 10 May 2007, Lasertec, C-492/04, ECR 2007 p. I-3775.

48 Judgment of 13 March 2007, Test Claimants in the Thin Cap Group Litigation. C-524/04, ECR 2007 p. I-2107.

49 See for example Council Regulation (EU) No 442/2011 of 9 May 2011 concerning restrictive measures in view of the situation in Syria.

50 Judgment of 20 February 1979, Rewe / Bundesmonopolverwaltung für Branntwein, 120/78, ECR 1979 p. 649.

51 Judgment of 3 February 1993, Veronica Omroep Organisatie / Commissariaat voor de Media, C-148/91, ECR 1993 p. I-487.

52 Judgment of 4 June 2002, Commission / Portugal, C-367/98, ECR 2002 p. I-4731. 
here it applies that it may not be a measure pursuing purely economic reasons (C-319/02 Manninen ${ }^{53}$.

\section{Finalisation - on the position of the „over-looked freedom” within the Internal Market}

For the purpose of functioning of the internal market, it is also important to define the relationship between the free movement of capital and other freedoms of the internal market. As in the case of free movement of goods and freedom to provide services, certain valuable values are transferred across national boundaries. Situations when one state of facts will potentially fall under legal regulation of several freedoms of the internal market cannot be excluded - e.g. movement of a foreign person who intends to start their business in another state by buying stock or share in a domestic company. Free movement of capital may be labelled as a complementary freedom, which means that in relation to other freedoms it has subsidiary character. When banknotes and coins, which are a valid means of payment, are physically transferred across borders, a question arises whether they are a thing = free movement of goods, or financial values $=$ free movement of capital and payments. The Court of Justice resolved this issue in case 7/78 Thompson ${ }^{54}$, when it stated that when coins and banknotes which are legal tender are transferred, it is not free movement of goods, but movement of capital or payments.

Free movement of capital (and especially the subcategory of payments) can be called a "service" freedom ${ }^{55}$ because movement of financial values across borders is connected with the exercise of other freedoms. Free movement of capital is linked to the free movement of persons, in particular the freedom of establishment (203/80 Casati $\left.^{56}\right)$. Entrepreneurs exercising their freedom of establishment must necessarily transfer certain amount of capital, which they intend to invest, across borders before starting a business in another Member State.

Also workers or moving citizens, who wish to move to another Member State, invest their assets here (e.g. purchase of real estate). Free movement of payments is closely connected with the free movement of goods and services (orders from abroad and payment for goods and services abroad ${ }^{57}$ ) and the free movement of persons - non-entrepreneurs (transfer of cash in order to cover subsistence costs abroad).

53 Judgment of 7 September 2004, Manninen, C-319/02, ECR 2004 p. I-7477.

54 Judgment of 23 November 1978, Thompson, 7/78, ECR 1978 p. 2247.

55 See LENAERTS, K., VAN NUFFEL, P.: European Union law. 3rd ed, London: Sweet and Maxwell, 2011, p. 285.

56 Judgment of 11 November 1981, Casati, 203/80, ECR 1981 p. 2595.

57 On the interrelations between free movement of capital and free movement of services see Judgment of 14 November 1995, Svensson and Gustavsson / Ministre du Logement et de l'Urbanisme, C-484/93, ECR 1995 p. I-3955. 
Free movement of capital is differentiated from other freedoms not only by slower liberalization but also by the territorial scope of this freedom. This freedom has global ${ }^{58}$ and absolute character. From the territorial point of view, it is the broadest freedom which applies erga omnes (to all investors) and therefore also outside the European Union. According to the Treaty, the prohibition of restrictions on movement of capital concerns both the movement between Member States of the Union, and movement between Member States and third countries. According to the Court, prohibition of restrictions on the free movement of capital is to be interpreted in the same way when it concerns movement within the Union, as well as when moving from or to third countries, and despite the fact that "the liberalisation of the movement of capital with third countries may pursue objectives other than that of establishing the internal market, such as, in particular, that of ensuring the credibility of the single Community currency on world financial markets and maintaining financial centres with a worldwide dimension within the Member States" $\left(C-101 / 05\right.$ Skatteverket $\left.{ }^{59}\right)$. The obligation of identical interpretation relates to the importance of the free movement of capital within the Union and outwards. The Court of Justice points out that in the law of the European Union (since the Maastricht Treaty came into effect) full liberalization of the free movement of capital between Member States and to and from third countries took place. This does not mean, however, that the scope of this freedom in the internal and external dimension is exactly the same. Treaty distinguished these dimensions when in the external dimension it allows a different (broader) package of exceptions ${ }^{60}$ from the prohibition of restrictions than in the internal dimension(C-446/04 Test Claimants in the FII Group Litigation $\left.{ }^{61}\right)$.

58 SUTTON, A. The Freedom of Capital Under Article 56 EC and its Application to Jurisdictions Outside the EU, White\&Case Study, march 2008. Available at: http://www.whitecase. com/files/Publication/8ab41a8d-b4bc-41f3-a2ec-f2d465259533/Presentation/PublicationAttachment/b8bde829-9409-41e2-914b-f9518f70e82e/memo_freedom_sutton.pdf.

59 Judgment of 18 December 2007, A, C-101/05, ECR 2007 p. I-11531.

60 See also USHER J. The Evolution of the Free Movement of Capital. Fordham International Law Journal, 2007, vol. 31, no. 5, pp. 1533-1570. (1569).

61 Judgment of 12 December 2006, Test Claimants in the FII Group Litigation, C-446/04, ECR 2006 p. I-11753. 